\title{
KEDUDUKAN DAN PARTISIPASI LEMBAGA ADAT DALAM PEMBENTUKAN PERATURAN PEKON DI PEKON WAY EMPULAU ULU KEC. BALIK BUKIT, KAB. LAMPUNG BARAT
}

\author{
Indah Maulidiyah MSK \\ Fakultas Hukum Universitas Lampung \\ E-mail : indahmmsk@gmail.com \\ Yusdiyanto dan Ahmad Saleh \\ Fakultas Hukum Universitas Lampung \\ Email: yusdiyanto@gmail.com
}

\begin{abstract}
This research aims to ascertain the position of Customary Institution in forming the Village Regulation, and also its role in the Way Empulau Ulu, Subdistrict - Balik Bukit, West Lampung. This research uses the method of normative-empirical; by doing library research, field research, and interviews. Results of the discussion showed that the Customary Institution of Way Empulau Ulu has the same position with the Institution of Rural Association. Although the Customary Institution has a position that is outside of organizational structure within the Village government, but the role of Customary Institution in forming the Village Regulation is just the structural and position of Customary Institution functionally is still less than optimal in the communication and interaction between the village government and the villagers.
\end{abstract}

Keywords: Position of Customary Institution, Participation of Customary Institution

\begin{abstract}
abstrak
Penelitian ini bertujuan untuk mengetahui kedudukan Lembaga Adat dalam pembentukan Peraturan Pekon, serta peran Lembaga Adat dalam pembentukan Peraturan Pekon di Pekon Way Empulau Ulu Kec. Balik Bukit, Kabupaten Lampung Barat. Metode penelitian yang digunakan adalah normatif empiris, yaitu dengan melakukan penelitian kepustakaan, penelitian lapangan dan wawancara. Hasil pembahasan ini menunjukkan bahwa Lembaga Adat di Pekon Way Empulau Ulu memiliki kedudukan yang sama dengan Lembaga Himpun Pemekonan. Walaupun Lembaga Adat memiliki kedudukan yang berada di luar susunan organisasi pemerintahan Pekon, namun peran Lembaga Adat dalam pembentukan Peraturan Pekon tersebut hanya sebatas struktural saja dan secara fungsional kedudukan Lembaga
\end{abstract}


Adat masih kurang optimal dalam komunikasi dan interaksi antara pemerintahan Pekon dan terhadap masyarakat Pekon.

Kata kunci : Kedudukan Lembaga Adat, Partisipasi Lembaga Adat

\section{A. Pendahuluan}

Negara Indonesia adalah negara kesatuan yang berbentuk Republik, demikian tersurat dalam Pasal 1 ayat (1) Undang-Undang Dasar (UUD) 1945, yang menunjukkan pilihan para pendiri negara (the founding father) bentuk negara (eenheidstaat, unitary state) bagi Indonesia, ${ }^{1}$ dengan mengakui dan menghormati kesatuan-kesatuan masyarakat hukum adat beserta hak-hak tradisionalnya yang berkembang dalam dinamika ketatanegaraan Indonesia.

Hal ini menunjukkan pengakuan adanya pemerintahan terendah di tingkat lokal yang disebut desa atau disebut nama lain, sebuah pemerintahan desa yang mendasarkan pada tata cara adat kebiasaan rakyat yang tidak tertulis. ${ }^{2}$ Adat kebiasaan masyarakat tradisional merupakan hukum rakyat dan dipatuhi demi tertibnya pergaulan masyarakat. Hukum rakyat itu tidak dibuat (by design), tetapi lahir, tumbuh, dan berkembang dari suatu masyarakat tradisional sederhana yang tercermin pada setiap tingkah laku individu-individu (law is from its social) ke masyarakat yang kompleks, dengan kesadaran hukum tampak pada ucapan-ucapan para ahli hukumnya. Desa mawa cara $^{3}$ dan negara mawa tata ${ }^{4}$, berarti masyarakat lokal dan negara berjalan berdasarkan dan menurut aturan masing-masing, tetapi berdampingan dan saling melengkapi. ${ }^{5}$ Makna dua hukum itu menjadikan semangat otonomi daerah semakin menemukan ruang geraknya, tidak saja dalam tataran konstitusi $^{6}$ dan seperangkat peraturan lain ${ }^{7}$, tetapi juga praktik-

\footnotetext{
1 Ateng Syafrudin dan Supri Na'a, Republik Desa : Pergulatan Hukum Tradisional dan Hukum Modern dalam Desain Otonomi Desa, (Bandung: P.T. Alumni, 2010), hlm.10.

2 Ade Saptomo. Hukum dan Kearifan Lokal: Revitalisasi Hukum Adat Nusantara. (Jakarta: Grasindo. 2010), hlm. 26.

${ }^{3}$ Desa mawa cara berarti "Cara", artinya kebebasan menentukan arah dan desa adalah lokus adat budaya yang memiliki beragam cara dalam menentukan arah kehidupannya. Karena desa sebuah kesatuan komunitas habitus, maka pemimpin desa adalah pemimpin adat "buyut" yaitu tetua untuk mengayomi adat istiadat atau kebiasan yang memiliki nilai luhur pengabdian pada aspek ketuhanan dan kemasyarakatan, peran buyut dalam suatu Desa.

${ }^{4}$ Negara mawa tata berarti negara sebagai pemerintah pusat dan hukum negara sebagai tata urutan hasil konstruksi eksekutif dan legislatif yang harus dipatuhi.

${ }^{5}$ Op.Cit. Ade Saptono. Hukum dan Kearifan Lokal........., hlm. 27.

${ }^{6}$ Op.Cit. Ade Saptono. Hukum dan Kearifan Lokal........., hlm. 27.

${ }^{7}$ Dalam Pasal 8 ayat (1) Undang-undang No. 12 tahun 2011 tentang Pembentukan Peraturan Perundang-undangan, bahwa Peraturan Desa atau disebut nama lain dibentuk oleh Undangundang atau Pemerintah Desa atas perintah Kepala Desa atau disebut nama lain.
} 
praktik sosial seperti mengadakan festival adat dan pertemuan antara tokohtokoh adat demi menjaga dan memelihara nilai-nilai budaya masyarakat yang bersangkutan terutama nilai-nilai etika, moral dan adab yang merupakan inti adat istiadat, kebiasaan-kebiasaan dalam masyarakat adat, dan Lembaga Adat, agar keberadaannya tetap hidup dan berlanjut ${ }^{8}$.

Objek penelitian yang akan dilakukan pada Pekon ${ }^{9}$ Way Empulau Ulu Kecamatan Balik Bukit Kebupaten Lampung Barat, hal ini dikarenakan bahwa di Pekon tersebut masih terdapat lembaga adat yang ditelusuri dari silsilah struktur masyarakat adat, yaitu masyarakat yang berkebudayaan Sai Batin memperlihatkan kedudukan dan posisi penting Sekala Brak sebagai satuan peradaban yang lengkap dan terwariskan.

Partisipasi dalam lembaga adat Lampung menjadi alasan untuk kemajuan pekon. Hal ini mencakup semua aspek pelaksanaan pembangunan, mulai dari penyusunan, pembahasan dan penetapan suatu peraturan pemekonan yang mendorong proses demokratisasi dapat berjalan dengan lancar. Pentingnya partisipasi lembaga adat dalam pembuatan ataupun perubahan peraturan pekon, yang berasal dari tuntutan dan dukungan masyarakat dan lembaga adat, kemudian ditelaah oleh LHP $^{10}$ (Lembaga Himpun Pemekonan) dan Peratin ${ }^{11}$, barulah dapat melahirkan output berupa peraturan pekon yang diberlakukan kepada seluruh masyarakat adat.

Peran serta lembaga adat, sangat berperan dalam pembuatan peraturan pekon guna menciptakan Pekon Way Empulau Ulu yang kaya akan budaya, adil, dan berkelanjutan. Keikutsertaan lembaga adat juga membuat nilai-nilai sosial budaya lokal yang menjadi satu titik kebersamaan antara masyarakat adat dengan pemerintahan daerah. Partisipasi sebagai dimensi yang harus meresapi seluruh perkembangan masyarakat, membutuhkan keterlibatan masyarakat. ${ }^{12}$ Bentuk partisipasi dari penyelenggaraan pemerintahan adalah pembuatan peraturan pekon yang usulkan oleh Peratin dan LHP (Lembaga Himpun Pemekonan), kemudian dibahas dan ditetapkan dalam suatu musyawarah. Bagaimana kedudukan lembaga adat dalam pembentukan

\footnotetext{
${ }^{8}$ Pasal 1 huruf (m) Peraturan Daerah No. 14 Tahun 2000 tentang Pemberdayaan, Pelestarian dan Pengembangan Adat Istiadat dan Lembaga Adat.

9 Pekon adalah sebutan lain di wilayah Kabupaten Lampung Barat yang berarti "Desa". Sebagaimana yang terdapat di wilayah sebagian daerah Lampung "Tiyuh, Kampung. Desa", Sumatera Barat "Nagari", Jawa "Desa" dan lain-lain.

10 Lembaga Himpun Pemekonan yang disingkat LHP adalah nama lain dari Badan Permusyawaratan Desa yang dipakai oleh desa yang berada di wilayah Kabupaten Lampung Barat. LHP Kabupaten Lampung Barat diatur dalam Peraturan Daerah No. 13 tahun 2006 tentang Susunan Organisasi dan Tata Kerja Lembaga Himpun Pemekonan.

11 Peratin adalah sebutan atau nama lain dari kepala desa yang dipakai oleh masyarakat Lampung di daerah Kabupaten Lampung Barat.

12 Johannes Muller. Perkembangan Masyarakat Lintas-Ilmu. (Jakarta: P.T. Gramedia Pustaka Utama. 2006), hlm. 257.
} 
Peraturan Pekon di Pekon Way Empulau Ulu Kecamatan Balik Bukit Kabupaten Lampung Barat dan bagaimana partisipasi lembaga adat dalam pembentukan Peraturan Pekon di Pekon Way Empulau Ulu Kecamatan Balik Bukit Kabupaten Lampung Barat?

\section{B. Pembahasan}

\section{Kedudukan Lembaga Adat Pekon Way Empulau Ulu dalam Pembentukan Peraturan Pekon}

Kedudukan lembaga adat masih diakui keberadaannya dengan syarat bahwa kelompok masyarakat hukum adat itu benar-benar ada dan hidup, bukan dipaksa-paksakan ada, bahkan bukan dihidup-hidupkan. Bahkan kedudukan Lembaga Adat di Pekon Way Empulau Ulu yang terdapat dalam Undang-Undang Dasar Negara Republik Indonesia tahun 1945 dalam Pasal 18 B ayat (2), yaitu:

"(2) Negara mengakui dan menghormati kesatuan-kesatuan masyarakat hukum adat beserta hak-hak tradisionalnya sepanjang masih hidup dan sesuai dengan perkembangan masyarakat dan prinsip Negara Kesatuan Republik Indonesia, yang diatur dalam undang-undang".

Merupakan ciri khas dari sebuah pekon di Kabupaten Lampung Barat. Pasal tersebut menyatakan bahwa dalam satuan pemerintahan di tingkat Pekon Way Empulau Ulu masih hidup berdasarkan adat dengan hak-haknya seperti hak untuk mengatur, mengurus, dan menyelesaikan berbagai permasalahan kehidupan yang berkaitan dengan adat istiadat dan hukum adat yang berlaku. Secara garis besar, bahwa telah diuraikan dalam UndangUndang Dasar Negara Republik Indonesia tahun 1945 pasal 18 B, oleh karena itu dalam pelaksanaannya lembaga adat di pekon tersebut memiliki pengaturan yang lebih rinci dalam peraturan daerah yang ditetapkan oleh DPRD Kabupaten Lampung Barat, namun tidak boleh bertentangan dengan prinsip-prinsip negara kesatuan.

Lembaga Adat diakui dan ditetapkan dalam Pasal 95 Undang-Undang No. 6 tahun 2014 tentang Desa. Lembaga adat yang telah terbentuk memiliki pengaturan dan pelaksanaan pemerintahan berdasarkan susunan asli, yaitu kewenangan lembaga adat yang berdasarkan hak asal usul lembaga adat tersebut. Pengaturan dan pengurusan ulayat atau wilayah adat yang dilakukan oleh lembaga adat juga wewenang lembaga adat, kemudian pelestarian nilai sosial budaya yang menjadi corak pekon Way Empulau Ulu sebagai pekon adat, serta lembaga adat berwenang dalam penyelesaian sengketa adat berdasarkan hukum adat yang berlaku di pekon dalam wilayah yang selaras dengan prinsip hak asasi manusia dengan mengutamakan penyelesaian secara musyawarah. Namun dalam hal tersebut sudah 
dipengaruhi oleh sistem pemerintahan yang secara nasional, yaitu dengan peraturan yang berlaku.

Kedudukan lembaga adat yang diatur dalam Peraturan Pemerintah No. 72 tahun 2005 tentang Desa berbeda, seperti yang telah dijelaskan dalam Pasal 30 ayat (2), yaitu:

"Anggota BPD sebagaimana dimaksud pada ayat (1) terdiri dari Ketua Rukun Warga, pemangku adat, golongan profesi, pemuka agama, dan tokoh atau pemuka masyarakat lainnya".

Badan Permusyawaratan Desa (BPD) atau disebut Lembaga Himpun Pemekonan (LHP) di wilayah Kabupaten Lampung Barat. Dalam Peraturan Pemerintah No. 72 tahun 2005 tentang Desa, BPD memiliki anggota yang di antaranya adalah pemangku adat yang bertugas membantu tugas BPD. Kedudukan pemangku adat yang berada di bawah pengawasan BPD membuat hak dan wewenang pemangku adat menjadi terbatas. Hal ini keberadaan pemangku adat tidak sepenuhnya optimal diimplementasikan kepada desa adat, melainkan hanya sebagai wadah apresiasi masyarakat dan akan dibahas dan ditentukan oleh BPD kemudian ditetapkan oleh Kepala Desa.

Dari penjelasan tersebut menurut penulis bahwa kedudukan lembaga adat yang terdapat pada Pekon Way Empulau Ulu adalah memiliki kedudukan yang berbeda dengan LHP. Bahkan bukan sebagai bagian dari LHP, tetapi sejajar dengan LHP, seperti yang sudah dijelaskan dalam Pasal 8 ayat (1) Peraturan Daerah Lampung Barat No.14 tahun 2000 tentang Pemberdayaan, Pelestarian Lembaga adat:

"Kedudukan Lembaga Adat adalah suatu wadah organisasi permusyawaratan/permufakatan Kepala Adat/Pemangku Adat, Petua-petua Adat dan Sai Batin/Pemuka-pemuka adat lainnya yang berada di luar susunan Organisasi Pemerintahan Kabupaten, Kecamatan, dan Pekon/Kelurahan".

Yaitu sebagai lembaga perwujudan demokrasi Pekon secara adat namun berkesinambungan dalam pemerintahan Pekon. Lembaga Adat yang berwenang dalam pengurusan kepentingan masyarakat adat dan memusyawarahkan berbagai hal yang menyangkut masalah-masalah adat ataupun keperluan adat dan agama untuk kepentingan Pekon tersebut, tetapi juga berwenang dalam pembentukan dan penetapan peraturan Pekon selama tidak bertentangan dengan aturan-aturan adat yang sudah berlaku sejak Pekon Way Empulau Ulu belum memasuki ranah pemerintahan. Tetapi jika terdapat perbedaan pendapat antara Lembaga Adat dengan Aparat Pemerintah di Daerah, diselesaikan secara musyawarah yang mufakat. Apabila tidak berhasil diselesaikan, maka upaya penyelesaian haruslah dilakukan oleh Kepala Adat Wilayah dan Lembaga Adat yang lebih tinggi 
tingkatannya dengan memperhatikan kepentingan masyarakat adat setempat. ${ }^{13}$

Selain Peratin, lembaga adat dan LHP di Pekon Way Empulau Ulu yang merupakan komposisi utama dalam struktur organisasi pemerintahan Pekon, Sekretaris Pekon, Kepala Urusan, dan Kepala Dusun merupakan perangkat Pekon yang menangani pemerintahan administrasi Pekon di bawah kewenangan Peratin. Struktur pemerintahan Pekon Way Empulau Ulu menurut arsip pemekonan adalah sebagai berikut :

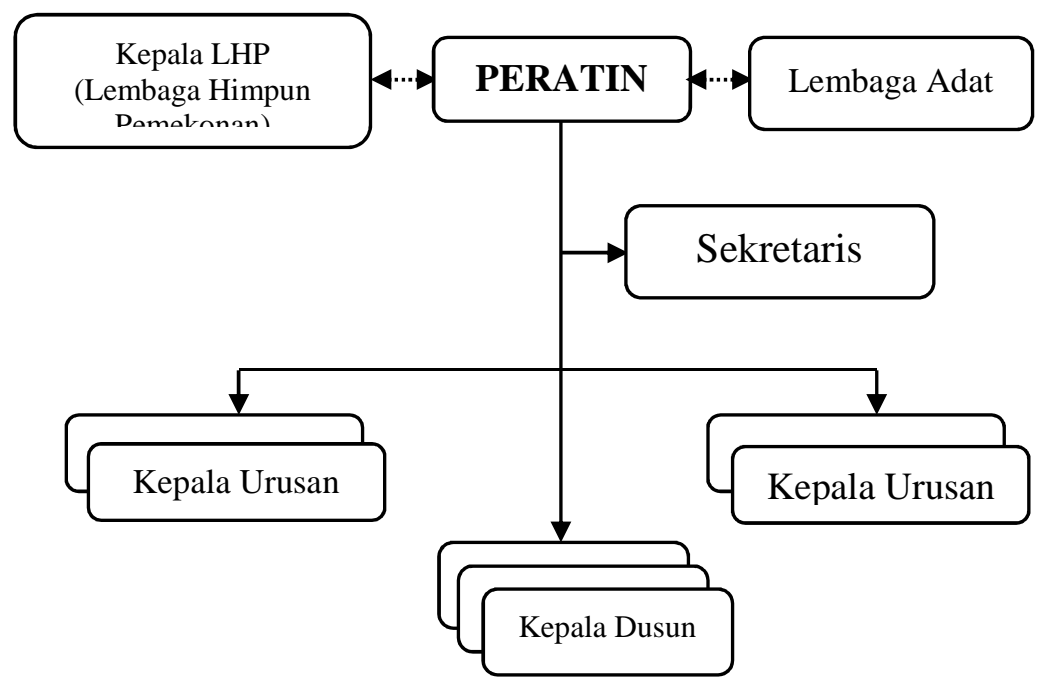

Bagan 1. Struktur Pemerintahan Pekon Way Empulau Ulu

Dijelaskan dalam PP No. 72 Tahun 2005 tentang Desa bahwa sistem pemerintahan dalam perumusan pembentukan peraturan pekon saat ini tidak sesuai dengan prosedur yang tercantum. Fauzi Taher ${ }^{14}$ memberikan keterangan bahwa:

"Perumusan rancangan pembuatan peraturan Pekon yang pertama tentang Larangan Memancing di Sawah Orang Lain mengundang seluruh tokoh adat dan tokoh-tokoh lainnya termasuk aparat pemekonan dan LHP. Pembuatan Peraturan Pekon dengan mengutamakan kebersamaan masyarakat setempat".

13 Pasal 8 ayat (1) Peraturan Daerah Lampung Barat No.14 tahun 2000 tentang Pemberdayaan, Pelestarian dan Pengembangan Adat Istiadat dan Lembaga adat.

${ }^{14}$ Wawancara dengan Fauzi Taher, mantan Peratin Pekon Way Empulau Ulu di kediamannya tanggal 19 September 2013, pukul 17.18-18.10 WIB. 
Pandri S. Dinata ${ }^{15}$ menjelaskan bahwa tokoh adat di Pekon Way Empulau Ulu adalah tokoh adat yang dipandang agung oleh masyarakat karena silsilah keturunan sebelumnya bukan karena derajat hartanya. Mat Shahril ${ }^{16}$ menuturkan bahwa sebagai tokoh adat tertua tidak mengetahui jika tokoh adat memiliki kedudukan di Pekon. Kemudian, sama halnya dengan pendapat Riza Pahlewi ${ }^{17}$ bahwasanya:

"Suara tua-tua adat masih sangat didengar oleh masyarakat adat Pekon Way Empulau Ulu. Tetua adat punya posisi dan wewenang tetapi tidak dioptimalkan oleh Peratin Pekon tersebut, dan yang sangat disayangkan adalah ketika pembentukan Peraturan Pekon tokoh-tokoh adat tidak dilibatkan, bukan hanya Peraturan Pekon bahkan musyawarah untuk merencanakan pembangunan Pekon saja tidak dilibatkan".

Struktur lembaga adat di Pekon Way Empulau Ulu merupakan komponen utama dalam suatu pemerintahan adat yang mana para pemangku adat masih menggunakan cara tradisional dalam memecahkan suatu masalah. Pemangku adat juga memiliki kewajiban terhadap Pekonnya seperti yang telah dijelaskan dalam Pasal 9 ayat (2) Peraturan Daerah Kabupaten Lampung Barat No. 14 Tahun 2000 tentang Pemberdayaan, Pelestarian, dan Pengembangan Adat Istiadat dan Lembaga Adat.

Mat Shahril merupakan penduduk dari Pekon Way Empulau Ulu yang memiliki gelar keturunan tertua yaitu Suntan Buay Betawang yang tidak mengenal bahkan tidak mengetahui bagaimana proses pembentukan peraturan pekon, kemudian Jus'a ${ }^{18}$ juga menambahkan bahwa, Pekon Way Empulau Ulu memiliki banyak tokoh adat, seharusnya dalam musyawarah tokoh adat dilibatkan, bukan hanya dalam masalah konflik. Bahkan Denti Afrina $^{19}$ mengungkapkan adanya penyimpangan wewenang yang terjadi dalam pemerintahan pekon terhadap pemerintahan adat, hal ini terlihat

15 Wawancara Pandri Surya Dinata, A.M.K.G., S.K.M. gelar Batin Puspa Marga, tokoh masyarakat sekaligus berprofesi sebagai ahli kesehatan gigi dan kesehatan masyarakat, di kediaman Riza Pahlewi gelar Raja Punyimbang Marga tanggal 15 September 2013, pukul 17.05-17.40 WIB.

16 Wawancara Mat Shahril bergelar Suntan Buay Betawang, Raja Jungku Lamban Bandar Agung, Sai Batin Gedung Dalom Marga Liwa, salah satu Tokoh Adat tertua di Pekon Way Empulau Ulu di kediamannya tanggal 16 September 2013, pukul 17.45-18.48 WIB.

${ }^{17}$ Wawancara Riza Pahlewi yang bergelar Raja Penyimbang Adat sekaligus mantan anggota LHP di kediamannya tanggal 18 September 2013, pukul 16.00-16.46 WIB.

${ }^{18}$ Wawancara Jus'a, salah satu tokoh masyarakat yang bekerja sebagai tukang urut, di kediaman Riza Pahlewi bergelar Raja Penyimbang Marga tanggal 18 September 2013, pukul 20.01-20.35 WIB.

${ }_{19}$ Wawancara Denti Afrina, A.Md. gelar Batin Puspa Marga, tokoh pemudi sekaligus berprofesi sebagai guru bahasa Inggris, di kediaman Riza pahlewi gelar Raja Punyimbang Marga tanggal 15 September 2013, pukul 17.05-17.40 WIB. 
dalam musyawarah yang terselubung antara aparat pemekonan terhadap pemangku adat.

\section{Partisipasi Lembaga Adat dalam Pembentukan Peraturan Pekon}

Penduduk asli Pekon Way Empulau Ulu yang terletak di Kabupaten Lampung Barat adalah Sai Batin, yang sebagian besar penduduknya menganut agama Islam yang sangat religius. Di kehidupan sehari-hari masyarakat pekon berpedoman pada adat istiadat yang sudah diwariskan secara turun-temurun, dan berpedoman pada nilai-nilai yang terdapat dalam ajaran agama Islam; sehingga sekarang ini adat istiadat atau sistem nilai budaya yang dijalankan masyarakat Pekon Way Empulau Ulu banyak bernuansa pada ajaran agama Islam.

Masyarakat adat dalam kehidupan bermasyarakat untuk menjalankan, mengawasi dan menegakan nilai atau adat istiadat, maka dibentuk Lembaga Adat yang sering disebut pemangku adat. Di dalam pemangku adat terdapat aturan-aturan informal yang disebut aturan adat, yang kemudian disepakati, dilaksanakan, dan dijadikan pedoman sebagai nilai normatif dalam kehidupan bermasyarakat. $^{20}$

Hal ini berkaitan dengan kebiasaan masyarakat terdahulu dan masih dilaksanakan hingga sekarang, namun sudah berubah dari waktu ke waktu. Musyawarah yang dilakukan tidak hanya dalam ruang lingkup masyarakat adat dan Lembaga Adat, melainkan masyarakat pekon yang bertempat tinggal di wilayah pekon tersebut juga dapat hadir dalam musyawarah untuk kemajuan Pekon Way Empulau Ulu menjadi lebih baik.

Sehingga dapat digambarkan dalam bagan sebagai berikut:

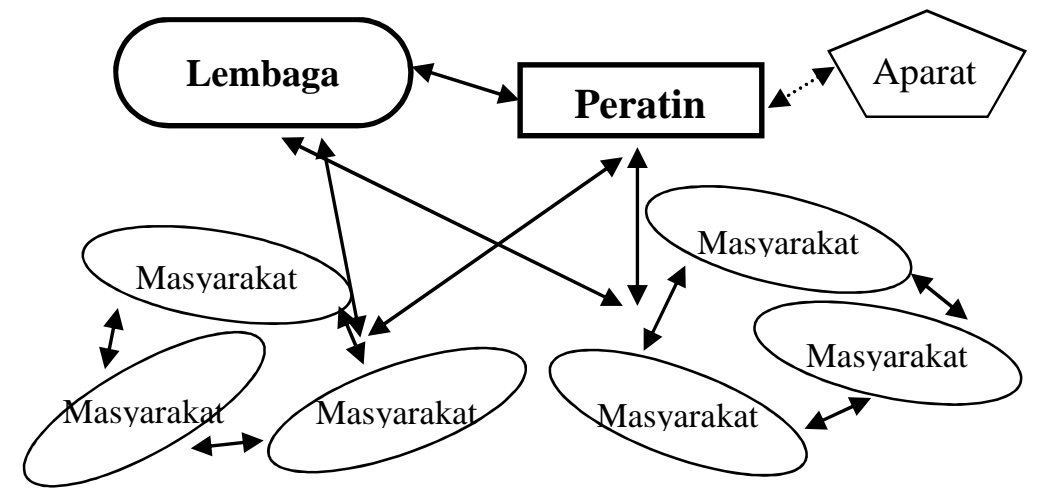

Bagan 2. Peran Lembaga Adat dalam Musyawarah

\footnotetext{
${ }^{20}$ M Rasyidi. Studi Nilai Budaya pada Lembaga Adat Suku Sasak sebagai Kekuatan dalam Membangun Nilai Leluhur Budaya Bangsa. Karya llmiah (Jurnal). Agroteksos Vol. 18 No. 1-3. 2008. Fakultas Pertanian Universitas Mataram: Mataram, hlm. 3.
} 
Berdasarkan penelitian yang dilakukan di Pekon Way Empulau Ulu, sebuah partisipasi yang baik dilakukan oleh Lembaga Adat Pekon, aparat pemerintahan Pekon, dan wakil-wakil masyarakat. Lembaga Adat dan masyarakat adat mengadakan musyawarah untuk pembentukan aturan adat yang bersifat menegakan keadilan dalam Pekon tersebut. Kemudian ditetapkan dan dijadikan sebagai landasan hukum bagi masyarakat Pekon.

Menurut Pandri Surya Dinata ${ }^{21}$ partisipasi merupakan kepedulian warga sebagai masyarakat pekon terhadap lingkungannya menuju pekon yang lebih baik. Fauzi Taher ${ }^{22}$ berpendapat bahwa,

"Partisipasi masyarakat adat adalah dorongan dari dalam diri seseorang yang tergabung dalam suatu kumpulan masyarakat pekon dan masyarakat adat untuk mengikuti serangkaian kegiatan tertentu yang bermanfaat untuk diri sendiri maupun untuk masyarakat di pekon tersebut".

Selanjutnya Mazarin ${ }^{23}$ juga menambahkan bahwa

"Partisipasi masyarakat sangat penting bagi masyarakat pekon dan Lembaga Adat di Pekon Way Empulau Ulu, karena Pekon Way Empulau Ulu tidak hanya terdiri dari masyarakat pribumi, tetapi terdiri dari masyarakat pendatang yang bertransmigrasi dari Jawa Tengah, Jawa Barat, Sumatera Utara, Sumatera Selatan, dan lainlain".

Selanjutnya Novan Adiputra ${ }^{24}$ menjelaskan bahwa partisipasi yang baik dan benar dalam wilayah Pekon adat dilakukan dengan mengupayakan Kepala Adat hingga anggota pembantu Kepala adat ikut andil dalam mengambil peran dalam penyelenggaraan pembentukan peraturan pekon. Tokoh-tokoh adat merupakan syarat utama musyawarah di Pekon adat sebagai bagian aspirasi yang menjangkau semua kalangan termasuk dalam pembentukan dan penetapan peraturan pekon di wilayah Pekon Way Empulau Ulu. Kemudian Denti Afrina ${ }^{25}$ juga berpendapat bahwa suara tokoh adat adalah pokok dari cikal bakal pembentukan peraturan pekon untuk kemajuan pekon tanpa harus menghilangkan kebudayaan yang sudah ada sejak zaman dahulu. Sesuai dengan emansipasi perempuan yang memiliki suami yang menjadi tokoh adat, memiliki hak untuk mengeluarkan pendapat,

\footnotetext{
${ }^{21}$ Op.Cit. Padri Surya Dinata.

${ }^{22}$ Op.Cit. Fauzi Taher.

${ }^{23}$ Wawancara dengan Mazarin, Sekretaris Pekon Way Empulau Ulu di kediamannya tanggal 16 September 2013, pukul 17.05-18.02 WIB

${ }^{24}$ Wawancara Novan Adiputra, S.Ag., merupakan salah satu Budayawan Lampung di Marga Liwa, wawancara melalui chat facebook tanggal 24 Desember 2013, pukul 00.57 WIB.

${ }^{25}$ Op.Cit. Denti Afrina.
} 
namun sedikit sekali presentasi yang mendukung ide-ide pihak perempuan, tutur Nurzati Bahri ${ }^{26}$.

Peraturan Pekon memiliki kedudukan yang setingkat dengan peraturan adat yang masih berlaku di Pekon tersebut. Peraturan Pekon yang berada di Pekon Way Empulau Ulu merupakan peraturan yang dibentuk berdasarkan kondisi sosial dan budaya masyarakat yang mengutamakan ketertiban hukum di pekon serta merupakan penjabaran lebih lanjut dari peraturan daerah Kabupaten Lampung Barat dan peraturan perundang-undangan yang lebih tinggi yang sesuai dengan gejala sosial tersebut. Berdasarkan Pasal 7 ayat (1), (2), (3) Permendagri No. 29 Tahun 2006 tentang Pedoman Pembentukan dan mekanisme Penyusunan Peraturan Desa menyatakan bahwa masyarakat berhak memberikan masukan baik secara tertulis maupun lisan terhadap rancangan peraturan desa yang dapat dilakukan dalam proses penyusunan rancangan peraturan desa. Mekanisme penggunaan hak tersebut diatur lebih lanjut dalam peraturan daerah kabupaten/kota. ${ }^{27}$

Di Pekon Way Empulau Ulu, pembentukan peraturan Pekon yang diusulkan oleh Peratin dan LHP (Lembaga Himpun Pemekonan) yaitu dengan membahas dalam sebuah musyawarah sebelum ditetapkan. Proses pembuatan peraturan Pekon akan berhasil baik apabila didukung oleh partisipasi seluruh warga masyarakat dan pemangku adat dengan menyampaikan aspirasinya dan juga kemampuan LHP di dalam menyerap aspirasi dari masyarakat maupun pemangku adat. Pasal 7 ayat (1) Peraturan Menteri Dalam Negeri No. 29 Tahun 2006 tentang Pedoman Pembentukan dan Mekanisme Penyusunan Peraturan Desa, yaitu masyarakat adat berhak memberikan masukan baik secara tertulis maupun lisan terhadap Rancangan Peraturan Desa. ${ }^{28}$ Keikutsertaan masyarakat adat juga membuat nilai-nilai sosial budaya lokal yang menjadi satu kesatuan antara masyarakat adat dengan pemerintahan daerah. Partisipasi masyarakat adat sebagai dimensi yang harus meresapi seluruh perkembangan Pekon yang membutuhkan keterlibatan seluruh penduduk Pekon ${ }^{29}$.

\footnotetext{
${ }^{26}$ Wawancara Nurzati Bahri gelar Batin Kemala, sebagai Tokoh Adat, di kediamannya tanggal 18 September 2013, pukul 16.00-16.46 WIB.

${ }^{27}$ Lembaran Daerah Kabupaten Tanggamus No. 24 tahun 2007 tentang Peraturan Pemekonan, dikutip dari Febri Kurniawan. Partisipasi Masyarakat dalam Pembentukan Peraturan Pemekonan Nomor 1 Tahun 2010 tentang Rencana Kegiatan Pembangunan Pekon Tahun Anggaran 2010 di Pekon Pujodadi Kecamatan Pardasuka Kebupaten Pringsewu Provinsi Lampung. (Skripsi). 2012, hlm. 38.

${ }^{28}$ Peraturan Menteri Dalam Negeri No. 29 Tahun 2006 tentang Pedoman Pembentukan dan Mekanisme Penyusunan Peraturan Desa.

${ }^{29}$ Johannes Muller. Perkembangan Masyarakat Lintas-Ilmu. (Jakarta: P.T. Gramedia Pustaka Utama. 2006), hlm. 257.
} 
Pasal 7 ayat (2) Peraturan Daerah Kabupaten Lampung Barat No. 14 Tahun 2000 tentang Pemberdayaan, Pelestarian, dan Pengembangan Adat Istiadat dan Lembaga $\mathrm{Adat}^{30}$, yaitu:

"Tujuannya adalah untuk mendorong, menunjang, dan meningkatkan partisipasi masyarakat guna kelancaran penyelenggaraan pemerintahan, pelaksanaan, pembangunan dan pembinaan masyarakat di daerah, khususnya di Pekon".

Berdasarkan hasil penelitian, sejak tahun 1862 hingga tahun 2014 Pekon Way Empulau Ulu terbentuk, pemangku adat pernah menetapkan beberapa peraturan adat, yaitu peraturan yang tidak tertulis berkembang dan dipatuhi oleh masyarakat. ${ }^{31}$ Peraturan tersebut sudah tidak berlaku karena ilmu pengetahuan logika dan teknologi yang maju. Sebagai contoh adalah aturan adat bagi mekhanai yang ingin bertamu ke rumah muli, yang diharuskan tidak melalui pintu utama, melainkan pintu belakang. Hal ini menandakan bahwa suatu sopan santun mekhanai terhadap orang tua muli. Tetapi karena perkembangan teknologi yang maju, maka sekarang sudah tidak berlaku karena handphone yang sudah sangat familiar digunakan oleh para bujang gadis.

Diketahui bahwa pemerintahan pekon telah menetapkan sebanyak dua peraturan pemekonan, yaitu 1) Peraturan Pekon tahun 1998 tentang Larangan Memancing di Sawah Orang Lain; dan 2) Peraturan Pekon tahun 2003 tentang Larangan Penebangan Pohon di Hutan Marga. Peraturan Pekon tentang Larangan Memancing di Sawah Orang Lain yang disusun dan ditetapkan secara musyawarah tahun 1998 ketika Pekon tersebut mengalami kejadian perbuatan yang merugikan orang lain dengan memancing ikan di sawah milik orang lain. Hal ini merupakan tindakan pertama yang dilakukan oleh pemerintahan pekon untuk mengantisipasi masyarakat pekon tidak mengulangi kejadian tersebut. Peraturan ini berlaku bagi siapa saja dengan sengaja melanggar. Sanksi yang digunakan adalah dihukum secara adat dan membayar denda sebesar Rp.500.000,- (Lima Ratus Ribu Rupiah) ${ }^{32}$.

Hal ini dilihat dari landasan hukum pemerintahan pekon sesuai dengan terjemahan Kitab Kuntara Raja Niti pada Pasal 1 dan pasal 14 Bab VI tentang Jugul Muda, yaitu:

Pasal 14: "Kalau ada orang mengatakan bahwa seseorang telah mencuri, nyata bersangkutan adalah orang baik-baik kemudian, kemudian kehilangan orang yang empunya harta maka orang yang membicarakan itu kena hukuman, yang dinamakan nyilam baya".

\footnotetext{
${ }^{30}$ Peraturan Daerah Kabupaten Lampung Barat No. 14 Tahun 2000 tentang Pemberdayaan, Pelestarian dan Pengembangan Adat Istiadat dan Lembaga Adat.

${ }^{31}$ Moh. Fadli, Jazim Hamidi, Mustafa Lutfi. Pembentukan Peraturan Desa Partisipasif (Head To A Good Village Governance). (Malang: Universitas Brawijaya Press. 2011), hlm. 88.

${ }^{32}$ Op.Cit. Fauzi Taher.
} 
Berdasarkan hasil penelitian Balai Penelitian Universitas Lampung, bahwa norma-norma dan nilai-nilai yang terkandung dalam Naskah Kuntara Raja Niti memiliki sistem budaya dan menunjukkan peradaban yang masih sangat tradisional, yaitu dari unsur agama, dirgama, dan karinah yang berarti suatu masalah dari kenyataan, perasaan hati nurani yang benar dan menilai latar belakang serta hubungan sebab akibat dari suatu permasalahan. ${ }^{33}$

Tahun 2003, pemerintahan pekon menetapkan Peraturan Pekon tentang Larangan Penebangan Pohon di Hutan Marga, yaitu pelanggaran yang dilakukan oleh beberapa warga Pekon Way Empulau Ulu menebang pohon di hutan dengan tidak mengindahkan syarat-syarat penebangan pohon yang baik. Sanksi yang diberikan adalah dihukum secara adat dan membayar denda yang dijelaskan dalam Peraturan Pekon tersebut ${ }^{34}$.

Bentuk partisipasi Lembaga Adat dalam penyelenggaran pemerintahan di wilayah Pekon Way Empulau Ulu belum dilakukan dengan optimal oleh aparat pekon, dan masyarakat. Proses pembentukan peraturan pemekonan tersebut dilakukan tanpa menghadirkan Lembaga Adat maupun tokoh masyarakat seperti yang diungkapkan Riza Pahlewi ${ }^{35}$ bahwa, partisipasi yang terdapat dalam pembentukan peraturan pekon tentang Larangan Memancing di Sawah Orang Lain serta Larangan Penebangan Pohon di Hutan Marga tidak mengikutsertakan pemangku adat ataupun tokoh masyarakat yang bersangkutan. Anton Makmur ${ }^{36}$ juga menjelaskan tidak adanya komunikasi dan interaksi yang baik antara pemerintahan pekon dan pemerintahan adat bahkan terhadap masyarakat pekon. Hal ini bertentangan dengan yang telah dijelaskan dalam Pasal 9 ayat (1) Peraturan Daerah Kabupaten Lampung Barat No. 14 Tahun 2000 tentang Pemberdayaan, Pelestarian, dan Pengembangan Adat Istiadat dan Lembaga Adat, yaitu:

a. mewakili Masyarakat Adat ke dalam dan keluar, yakni dalam hal-hal yang menyangkut kepentingan dan mempengaruhi Adat;

b. mengelola hak-hak Adat dan/atau harta kekayaan Adat untuk meningkatkan kemajuan dan taraf hidup masyarakatnya ke arah yang lebih layak dan baik; dan

c. menyelesaikan berbagai perselisihan yang menyangkut perkara-perkara Adat istiadat sepanjang penyelesaian itu tidak bertentangan dengan peraturan perundang-undangan.

\footnotetext{
${ }^{33}$ Op.Cit. Ali Imron dan Razi Arifin. Kuntara Raja Niti, hlm. 60.

${ }^{34}$ Op.Cit. Fauzi Taher.

${ }^{35}$ Op.Cit. Riza Pahlewi.

${ }^{36}$ Wawancara Anton Makmur, S.E. gelar Raja Punyimbang Marga II, sebagai Tokoh Adat, di kediaman Riza Pahlewi bergelar Raja Penyimbang Marga tanggal 15 September 2013, pukul 08.00-08.30 WIB.
} 
Terkait dalam mekanisme pembentukan peraturan Pekon Jus'a ${ }^{37}$ berpendapat bahwa sebagai tokoh masyarakat tidak mengetahui adanya musyawarah yang dilaksanakan, dan tidak pernah menerima undangan atau ajakan dari aparat pemekonan dalam bermusyawarah. Jus'a juga menuturkan kepentingan pekon adalah kepentingan masyarakat bersama dan pemerintah pekon harus mengupayakan apa yang menjadi tolok ukur pemerintahan pekon adanya masyarakat madani sehingga mengetahui pentingnya akan produk hukum di pekon tersebut.

Supnir Lutfi ${ }^{38}$ menjelaskan bahwa dalam proses pembentukan peraturan pekon dilakukan atas dasar kepentingan bersama, disetujui dan dilaksanakan sesuai dengan peraturan yang telah ditetapkan. Selanjutnya Mazarin $^{39}$ memberikan keterangannya bahwa mekanisme penyusunan dan penetapan suatu peraturan Pekon yang baik adalah dengan melibatkan seluruh tokoh-tokoh masyarakat dan adat serta anggota masyarakat agar menghasilkan peraturan Pekon yang baik dan sesuai dengan keadaan di wilayah Pekon Way Empulau Ulu. Mazarin ${ }^{40}$ juga menjelaskan bahwa,

"Peraturan Pekon adalah hak paten dari Pekon itu sendiri. Di dalam pembentukan dan penetapan Peraturan Pekon harus melibatkan tokoh adat. Semestinya, selain Lembaga Adat, tokoh agama, tokoh pemuda, dan tokoh masyarakat lainnya juga harus dilibatkan guna mencapai musyawarah yang mufakat. Prosedur pembuatan Peraturan Pekon yang menentukan adalah tokoh-tokoh adat. Walau tokoh-tokoh adat tidak menyetujui rancangan Peraturan Pekon, Peraturan tersebut tidak sah. Peraturan Pekon yang telah ditetapkan oleh Peratin harus disosialisasikan ke masyarakat, biasanya dilakukan melalui beberapa masjid sewaktu menunaikan sholat jum'at".

Bentuk partisipasi Lembaga Adat dalam penyelenggaran pemerintahan di wilayah Pekon Way Empulau Ulu belum dilakukan dengan optimal oleh aparat pekon, dan masyarakat. Proses pembentukan peraturan pemekonan tersebut dilakukan tanpa menghadirkan Lembaga Adat maupun tokoh masyarakat seperti yang diungkapkan Riza Pahlewi ${ }^{41}$ bahwa, partisipasi yang terdapat dalam pembentukan peraturan pekon tentang Larangan Penebangan Pohon di Hutan Marga tidak mengikutsertakan pemangku adat ataupun tokoh masyarakat yang bersangkutan. Anton

\footnotetext{
${ }^{37}$ Op.Cit. Jus'a.

38 Wawancara Supnir Lutfi, Peratin Pekon Way Empulau Ulu Kec. Balik Bukit Kabupaten Lampung Barat di kediamannya tanggal 16 September 2013, pukul 16.32-17.00 WIB.

${ }^{39}$ Op.Cit. Mazarin.

${ }^{40}$ Op.Cit. Mazarin.

${ }^{41}$ Op.Cit. Riza Pahlewi.
} 
Makmur ${ }^{42}$ juga menjelaskan tidak adanya komunikasi dan interaksi yang baik antara pemerintahan pekon dan pemerintahan adat bahkan terhadap masyarakat pekon. Hal ini bertentangan dengan yang telah dijelaskan dalam Pasal 9 ayat (1) Peraturan Daerah Kabupaten Lampung Barat No. 14 Tahun 2000 tentang Pemberdayaan, Pelestarian, dan Pengembangan Adat Istiadat dan Lembaga Adat, yaitu:

a. mewakili masyarakat adat ke dalam dan keluar, yakni dalam hal-hal yang menyangkut kepentingan dan mempengaruhi adat;

b. mengelola hak-hak adat dan/atau harta kekayaan adat untuk meningkatkan kemajuan dan taraf hidup masyarakatnya ke arah yang lebih layak dan baik; dan

c. menyelesaikan berbagai perselisihan yang menyangkut perkara-perkara adat istiadat sepanjang penyelesaian itu tidak bertentangan dengan peraturan perundang-undangan.

Terkait dalam mekanisme pembentukan peraturan Pekon Jus'a ${ }^{43}$ berpendapat bahwa sebagai tokoh masyarakat tidak mengetahui adanya musyawarah yang dilaksanakan, dan tidak pernah menerima undangan atau ajakan dari aparat pemekonan dalam bermusyawarah. Jus'a juga menuturkan kepentingan pekon adalah kepentingan masyarakat bersama dan pemerintah pekon harus mengupayakan apa yang menjadi tolok ukur pemerintahan pekon adanya masyarakat madani sehingga mengetahui pentingnya akan produk hukum di pekon tersebut.

Selanjutnya Eva Oktarina ${ }^{44}$ menjelaskan, bahwa:

"Generasi muda adalah cikal bakal penerus generasi terdahulu yang diberikan pengetahuan dan kemampuan berpartisipasi oleh masyarakat serta tokoh masyarakat dalam pembentukan peraturan pekon untuk ketertiban dan kemajuan Pekon Way Empulau Ulu, sehingga masyarakat dan tokoh masyarakat dalam pekon Way Empulau Ulu memberikan contoh yang baik dan mencerminkan sikap partisipasi yang diteladani oleh generasi muda".

Pendidikan sejak dini yang dilakukan oleh sekolah-sekolah merupakan inisiatif guru-guru untuk mengajarkan bagaimana menjadi pribadi pemimpin yang baik dan mengembangkan tingkat daya guna pekon tersebut. Hal ini dilakukan dengan mengembangkan potensi anak sekolah dengan aktif berorganisasi sosial maupun organisasi budaya.

Berdasarkan hasil penelitian diatas bahwa dapat dilihat dari keterangan masyarakat di Pekon Way Empulau Ulu merupakan kegiatan

\footnotetext{
${ }^{42}$ Op.Cit. Anton Makmur.

${ }^{43}$ Op.Cit. Jus'a.

${ }^{44}$ Wawancara Eva Oktarina, S.Pd., M.M. gelar Batin Penyanjung sebagai Akademisi, di Kecamatan Sukau Kabupaten Lampung Barat tanggal 17 Oktober 2013 pukul 11.00-11.15 WIB.
} 
yang kurang aktif dalam partisipasi maupun kegiatan lain. Salah satu faktor penting yang menghambat dalam mengupayakan mufakat dalam musyawarah pembentukan peraturan pekon adalah ketidaktahuan serta ketidakfahaman masyarakat maupun Lembaga Adat pekon.

Kurang keaktifan partisipasi dalam pembentukan peraturan pekon membuat masyarakat adat dan Lembaga Adat tidak memperhatikan arti pentingnya interaksi sosial dalam segala kegiatan-kegiatan yang ada dalam Pekon tersebut. Ahmadi ${ }^{45}$ menjelaskan bahwa rata-rata masyarakat adat dan Lembaga Adat pekon tidak peka dengan penyelenggaraan pemerintah pekon, sehingga masyarakat pekon cenderung pasif dan monoton terhadap kegiatan pemerintahan termasuk pembentukan dan penetapan peraturan pekon. Ada beberapa faktor yang menghambat kelancaran pemerintahan pekon, yang pertama faktor kesadaran masyarakat adat dan Lembaga Adat pekon sendiri, kedua kurangnya ajakan dari pemerintah pekon, dan ketiga Sumber Daya Manusia yang rendah akan tingkat pendidikan.

\section{Penutup}

\section{Kesimpulan}

a. kedudukan lembaga adat yang terdapat pada Pekon Way Empulau Ulu adalah memiliki kedudukan yang berbeda dengan LHP. Akan tetapi bukan sebagai bagian dari LHP, tetapi sejajar dengan LHP. Kemudian kedudukan lembaga adat dalam pembentukan peraturan pekon masih sangat didengar oleh masyarakat adat Pekon Way Empulau Ulu. Tetua adat punya posisi dan wewenang, namun tidak dioptimalkan oleh Peratin Pekon, pemekonan halnya dalam pembentukan Peraturan Pekon tokohtokoh adat tidak dilibatkan, bukan hanya Peraturan Pekon bahkan musyawarah untuk merencanakan pembangunan Pekon saja tidak dilibatkan.

b. peran partisipasi Lembaga Adat di Pekon Way Empulau Ulu secara garis besar adalah sebagai penyalur aspirasi masyarakat dan sebagai penasehat dalam ruang lingkup Pekon. Komunikasi dan interaksi yang kurang baik antara pemerintahan dan Lembaga Adat membuat hilangnya arti penting dari kesatuan dalam membangun Pekon Adat.

\section{Saran}

Berdasarkan kesimpulan yang telah diuraikan di atas, penulis menyarankan agar dilakukan:

\footnotetext{
${ }^{45}$ Wawancara Ahmadi, S.H., tokoh pemuda sekaligus pelopor Festival Marga Liwa di Pekon Way Empulau Ulu, di Fakultas Hukum Universitas Lampung tanggal 21 Desember 2013, pukul 11.18-12.00 WIB.
} 
a. perlu adanya komunikasi yang baik antara lembaga adat dan pemerintah pekon, dan transparansi antara lembaga adat dan pemerintah pekon terhadap masyarakat Pekon Way Empulau Ulu atas hal-hal yang wajib dimusyawarahkan;

b. untuk mendorong masyarakat berpartisipasi dalam pembentukan peraturan pekon, sosialisasi harus selalu dilaksanakan oleh pihak pemerintah pekon dan LHP, agar lembaga adat selalu dilibatkan, sehingga pembentukan peraturan pekon dapat menghasilkan produk hukum yang baik, dipahami, dan dimengerti oleh seluruh anggota masyarakat; dan

c. diharapkan di masa yang akan datang harus diatur secara tegas dan jelas mekanisme pembentukan peraturan pekon kepada peratin dan LHP terhadap lembaga adat dan tokoh-tokoh masyarakat lainnya, serta diaktifkannya kembali segala kegiatan pemerintahan pemekonan.

\section{Daftar Pustaka}

\section{A. Buku}

Fadli, Moh, Jazim Hamidi, dan Mustafa Lutfi, 2011. Pembentukan Peraturan Desa Partisipasif (Head To A Good Village Governance), Malang: Universitas Brawijaya Press.

Imron, Ali dan Razi Arifin, 1991. Kuntara Raja Niti (Transkripsi Naskah Kuno dan Analisis Sejarah), Lampung,Penerbit Universitas Lampung.

Muller, Johannes, 2006. Perkembangan Masyarakat Lintas-Ilmu, Jakarta: PT Gramedia Pustaka Utama.

Rasyidi, M., 2008. Studi Nilai Budaya pada Lembaga Adat Suku Sasak sebagai Kekuatan dalam Membangun Nilai Leluhur Budaya Bangsa, (Jurnal), Agroteksos Vol, 18 No, 1-3, Fakultas Pertanian, Mataram: Universitas Mataram.

Saptomo, Ade, 2010. Hukum dan Kearifan Lokal: Revitalisasi Hukum Adat Nusantara, Jakarta: Grasindo.

Syafrudin, Ateng, dan Supri Na'a, 2010. Republik Desa "Pergulatan Hukum Tradisional dan Hukum Modern dalam Desain Otonomi Desa", Bandung: PT Alumni.

\section{B. Peraturan Perundang-undangan}

Undang-Undang Dasar Negara Republik Indonesia tahun 1945.

Undang-undang No. 12 Tahun 2011 tentang Pembentukan Peraturan Perundang-undangan. 
Peraturan Menteri Dalam Negeri No. 29 Tahun 2006 tentang Pedoman Pembentukan dan Mekanisme Penyusunan Peraturan Desa.

Peraturan Daerah Kabupaten Lampung Barat No. 14 Tahun 2000 tentang Pemberdayaan, Pelestarian dan Pengembangan Adat Istiadat dan Lembaga Adat. 